\title{
Young Wome n's Dismissal of the Influence of Gender Upon Their Future Life Trajectory As Played Out in 'New Times'
}

\author{
Abstract \\ This paper investigates the ways in which young women come to view gender as being an \\ influence upon their future lives - their aspirations and expectations for the future. In doing \\ so, it draws upon 327 surveys completed by Year 12 female students - those typically 17 \\ years of age - in a range of schools across the State of Queensland, Australia. The paper \\ details key features of the young women's survey responses - the dominant storylines evident \\ in the data - as a means of illustrating how they have come to dismiss gender as an influence. \\ Further, the paper illuminates the power and pervasiveness of neoliberal discourse in 'New \\ Times', and the ways in which the young women surveyed embrace neoliberalism and its \\ imperative of individualisation - and do so in ways that locate gender as irrelevant in their \\ imagining and enacting of their life biographies. Finally, the paper explores the implications \\ of such research findings for these - and other - young women.
}

\section{Introduction}

This paper explores the ways in which young women - living in 'New Times' - come to view gender as an influence upon their future life trajectories. That is, what influence do they see gender as having upon their aspirations and expectations for the future, for the ways in which they hope to live out, enact, their desired futures? Given that these young women are indeed living in New Times, this paper frames its discussion of the influence of gender within the broader context of the discourse synonymous with such times - neoliberal discourse - and its imperative of individualism. 
In doing so, the paper examines survey data collected during the undertaking of a larger Australian Research Council (ARC) project. More specifically, it draws upon surveys completed by Year 12 female students - those typically 17 years of age - in a range of schools across the State of Queensland, Australia.

\section{A Contextual Framework}

Young women today - indeed in the Western world - are living out their lives within 'New Times', an age of modern liberalism - that generally referred to as neoliberalism. Neoliberalism is, as Davies, Browne, Gannon, Honan and Somerville (2005, p. 344) argue, “characterised by the 'death of society' and the rise of 'individuals' who are in need of a new kind of management, surveillance and control”. Neoliberalism, as Rose (1996a, p. 41) asserts: "does not seek to govern through "society", but through the regulated choices of individual citizens, now constructed as subjects of choices and aspirations of selfactualization and self-fulfilment. Individuals are, as such, to be governed through their freedom ...”. Thus, imperative to the neoliberal agenda, is the heightened focus on the individual, and the increased acceptance of personal responsibility - that is, the process of individualisation (see Beck, 1992; Beck \& Beck-Gernsheim, 2001, 2002).

Furthermore, there is, as Beck and Beck-Gernsheim (2001, p. 22) advocate, "hardly a desire more widespread in the West today than to lead 'a life of your own'”. Elaborating upon this notion, they suggest that:

The ethic of individual self- fulfilment and achievement is the most powerful current in modern society. The choosing, deciding, shaping human being who aspires to be the author of his or her own 
life, the creator of an individual identity, is the central character of our time (Beck \& Beck-Gernsheim, 2001, pp. 22-23).

Rose (1999, p. 95) similarly argues that "we have come to relate to ourselves as creatures of self-responsibility and self-mastery, with the capacity to transform ourselves and make our own lives the object of practices of self-shaping”.

Explaining the phenomenon of individualisation, Beck and Beck-Gernsheim (2001, p. 2) state that, "people are tied into a network of regulations, conditions and provisos. ... The decisive feature of these modern regulations or guidelines is that, far more than earlier, individuals must, in part, supply them for themselves, import them into their biographies through their own actions” (see also Beck \& Beck-Gernsheim, 1996).

Essentially, neoliberalism (re)casts the modern subject - the individual. For, it is the case that, these late modern - neoliberal - times "demand citizens who are flexible and selfrealizing" and who demonstrate the capacity to "regulate themselves through the right choices” (Harris, 2004, p. 2). Constitution of the self as a rational, autonomous, responsible and active Subject - a subject identifiable as the 'entrepreneurial self' - is prioritised within neoliberal discourse (Bauman, 1992; Rose, 1992, 1996a, 1996b; O’Malley, 1996; Beck \& Beck-Gernsheim, 2001; Fitzsimmons, 2002; Harris, 2004; Davies et al., 2005; Kelly, 2006). Every human being is positioned as "an entrepreneur managing their own life, and should act as such” (Fitzsimmons, 2002, p. 3); are positioned as “active individuals seeking to “enterprise themselves”, to maximize their quality of life through acts of choice (Rose, 1996a, p. 57; see also Rose, 1992, 1996b). Each individual is constitutive of a "particular ethics of the self $-\mathrm{a}$ form of personhood we can describe as the entrepreneurial Self, and a form of 
personhood that sees individuals as being responsible for conducting themselves, in the business of life, as an enterprise, a project, a work in progress” (Kelly, 2006, p. 18).

Further, individuals are "peremptorily invited to constitute themselves as individuals: to plan, understand, design themselves and act as individuals - or, should they 'fail', to lie as individuals on the bed they have made for themselves” (Beck \& Beck-Gernsheim, 2001, pp. 2-3). So, too, Beck and Beck-Gernsheim (2001, p. 4) advocate that "one of the most decisive features of individualization processes, then, is that they not only permit but they also demand an active contribution by individuals”.

With regard to this, the individual has to be understood as being "the author of his or her own life” (Beck \& Beck-Gernsheim, 2002, p. 23). Such “self narration” has, as Steedman (2000, pp. 26-27) argues, “come to be emphasized again and again as formative, constitutive of the subject of modernity”. Further as, Beck and Beck-Gernsheim (2001, p. 3) advance, "the normal biography thus becomes the 'elective biography', the 'reflexive biography', the 'do-ityourself' biography”" and that "this does not necessarily happen by choice, neither does it necessarily succeed”. Rather - and as advocated here, serving as a cautionary tale - they suggest that, “the do-it-yourself biography is always a 'risk biography', indeed a 'tightrope biography', a state of permanent (partly overt, partly concealed) endangerment” and that "the do-it-yourself biography can swiftly become the breakdown biography” (Beck \& BeckGernsheim, 2001, p. 3). In light of this, Beck and Beck-Gernsheim (2001, p. 16) suggest that, “individualization has a double face: 'precarious freedoms'”. Further, and in a similar vane, Beck, Bons and Lau (2003, p. 24) suggest "the agents of individualisation are also its victims". 
It is within this discursive construct of a contemporary world - one constituted by and within neoliberal discourse and its imperative of individualisation, and marked by the complexities at play in such discourse and the act of constructing the self - that young women come to imagine and live out their lives. That is, they come to (or 'fail' to) draw upon the available cultural scripts of the time to build (or 'fail' to build) a portfolio of identities, to author (or not) their own biographies - their biography of the self. And of interest in this paper are the ways in which young women, in imagining their biographies, come to view the influence of gender upon the construction of the narratives of their lives. For it must be acknowled ged that such biography work is also gendered work. Failure to acknowledge such is dangerous to run the risk of buying into the "epistemological fallacy" (Furlong \& Cartmel, 1997) that underlies the notion of 'choice biographies'. That is, to underestimate the extent to which the biographies they are shaping are still constrained by structural factors such as gender (see Dwyer \& Wyn, 2001). Identity - and indeed gender identity - is, in these New Times, dependent upon decision making, risk taking and reflexive action. As Rose (1996b, p. 302) asserts, "identity is no longer experienced as a natural, coherent and unchanging attribute of the individual, but as the uncertain and fractured result of personal decisions and plans. Biography and identity become self-reflexive, to be constructed, worked upon, the outcome of choices ... in which the individual himself or herself is the self-conscious centre of action.”

There have been, in the Western world since the 1960s, a number of structural changes in social sectors - for example, in relation to education, work, the legal system and the family which have served to reshape the construction of one's biography. The impact of these changes, however, is marked out as gender differentiated and social inequalities between men and women persist. 
In relation to women, the rapid changes that have occurred in the context of their lives, particularly in the last 20 years, are marked by a general discernible line of movement - a move away from “'living for others"” towards 'a bit of a life of our own”” - and one that “implies a complex, multi-layered and contradictory process” (Beck \& Beck-Gernsheim, 2002, p. 55). As Beck and Beck-Gernsheim (2002, pp. 55-56) advocate:

... the female biography underwent an 'individualization boost'. ... It opened up new scope for action and decision and new chances for women. But just as plainly it brought new uncertainties, conflicts and pressures. For now women had to face risks to which only men had previously been exposed - as well as further risks resulting from the fact that for women the individualization process was 'incomplete', was trapped in a peculiar intermediate stage. [original italics]

... This 'no longer' and 'not yet' generate numerous ambivalences and contradictions in women's lives.

... There is no longer any 'model' that defines women's life prospects - they are both more open and less protected than before.

Essentially, the transpiring social changes have served to alter the fundamental conditions of the female biography. However, while these “'external' givens of the female biography” have been "supported and reinforced by a newly emerging 'rhetoric of equality'” (Beck \& BeckGernsheim, 2002, p. 102) and "expectations of equality and fairness in relations between the sexes develop in [this] process - at least partially”, it is nonetheless the case that, "in everyday life there is little support for these expectations; in other words, not much has been done to 
follow up the rhetoric of equality with a reshaping of social practice” (Beck \& BeckGernsheim, 2002, pp. 102-103).

Research conducted by Lopez-Claros and Zahidi (2005) for the World Economic Forum highlights such existing gender inequalities. Seeking to assess the size of the gender gap, this study measured the extent to which women in 58 countries - 30 OECD countries and 28 other countries from the "emerging market” world - had achieved equality with men. What emerged from this study was a "disheartening” picture, for it was the case that, as the research reports, "even in light of heightened international awareness of gender issues, it is a disturbing reality that no country has yet managed to eliminate the gender gap” (Lopez-Claros \& Zahidi, 2005, p. 1). With regard to Australia, an overall score of 4.61 - with scores reported on a scale of 1 to 7 , with 7 representing maximum gender equality - and the subsequent ranking of $10^{\text {th }}$ in the world was attained (see Lopez-Claros \& Zahidi, 2005, p. 8).

Clearly, there exist obstacles within current social structures - obstacles that serve to insidiously establish new inequalities and hierarchies in the relationship between the sexes, and that serve to disenfranchise women. Given this, it is important to acknowledge that it is as gendered individuals located in such a context - a discursively constituted context and one marked out as unstable and risky - that today's young women come to imagine and enact their biographies. It is within this context that they come to constitute themselves as subjects - as gendered subjects (Davies, 1993).

Shifting focus, research pertaining to young people's aspirations and expectations has long been on the national and international agenda, and in general terms, such research has focused on their hopes and plans for the future and most notably their educational and employment 
futures. Such research conducted in Australia - as relating to the various factors that are seen to generally affect the formation of aspirations and expectations of young people - has identified the following broad categories: experiences of schooling (Ainley \& McKenzie, 1999; Trent \& Slade, 2001; Alloway, Dalley, Patterson, Walker \& Lenoy, 2004; Alloway, Gilbert, Gilbert \& Muspratt, 2004), families (Abbott-Chapman, 2000; Bryce \& Anderson, 2008) ethnicity and race (Kenyon, Sercombe, Black \& Lhuede, 2001; Mercurio \& Clayton, 2001;) gender (Gilbert \& Gilbert, 1995; Dwyer, Harwood \& Tyler, 1998; Collins, Kenway \& MacLeod, 2000) and socio-economic factors (Collins et al., 2000; James, 2001). Additionally, Marks, Fleming, Long and McMillan (2000) have shown that the role of attitudes, motivations and aspirations is just as influential, and their work points to the need for research which considers the narratives young people use when they imagine and aspire to particular futures and pathways (see also Dusseld orp Skills Forum, 2006a, 2006b).

Undertaking research such as that prioritised by Marks et al. (2000), an Australian-wide study reported that the vast majority of student participants who were interviewed indicated that they wanted 'to be something' - they wanted to make something of their lives - they did not want to be caught in what they perceived to be dead-end jobs that would rob them of opportunities to explore life (Alloway, Gilbert, Gilbert \& Muspratt, 2004). Additionally, many of these students considered their futures within an implicit framework of New Times of restructured communities and economies, of changing landscapes, and of meta-narratives that had begun to shape and coerce what they imagined and expected of themselves. So, too, the study reported that many students had thought about their futures in detailed ways and that they had accumulated know how and 'street savvy' that would assist them in navigating their futures. Overall, there existed generally buoyant levels of aspirations and expectations - as evident in the students' talk. Comparable findings were documented in research undertaken 
by Wyn and Woodman (2006, p. 508), who found that young Australians are "quite positive about their own possibilities" and have "embraced the idea of building a life" for themselves (see also Dwyer \& Wyn, 2001; Woodman, 2004). Similarly, a study of people aged 16 to 24 years in Australia noted that the young people who participated demonstrated a "robust selfconfidence that if they worked hard, with ordinary luck they could make their future happen” (Dusseldorp, 2006a, p. 40). These young people revealed a "strong streak of self-reliance and determination” (Dusseldorp, 2006a, p. 40).

Research has also reported that “young people’s future thinking combines ideas about ‘destinations' (what sort of job I would like) and desires about being and becoming a certain type of person", and indicates that "these are not neatly separable orientations" (McLeod \& Yates, 2006, p. 104; see also Yates \& McLeod, 2007). So, too, research has indicated that young people make the transition from their schooling lives to their post-schooling lives in a variety of ways: that the transition to adult life is not necessarily linear or predictable (Furlong \& Cartmel, 1997; Dwyer et al., 1998, 1999; Looker \& Dwyer, 1998); that many young people do not necessarily aspire to move directly from school to further education or training or employment. Rather, research has indicated the complex mix of work, study and leisure that constitutes young people's lives as they negotiate and navigate their way through a rapidly changing set of social, personal and employment conditions typical of the $21^{\text {st }}$ Century - the “New Times” (Wyn, 2004; see also Dwyer, 2000; Wyn \& Woodman, 2006; White \& Wyn, 2008). This marks out, significantly, a change from 'traditional' post-school trajectories - and is indicative of young people's response to the changing social and economic world within which they now live out their lives. 
Further, and in relation to the influence of gender upon young people’s aspirations and expectations for the future, research by Dwyer et al. (1998) indicated that gender remained a key factor in determining education and career choices. These strongly gendered differences in aspirations for the future were also identified in young people's schooling lives. As Collins et al. (2000, p. 2) have noted, "there are indeed major gender differences in educational participation, performance and outcomes” for young Australians.

Research conducted by McLeod and Yates (2006) also foregrounded difference around the 'marker' of gender. In relation to girls, they reported that many spoke about their "ambitions for independence and excitement” (McLeod \& Yates 2006, p. 225). So, too, they noted elsewhere, that many of the girls were aware of the "new possibilities of work and education" and engaged in "making clear plans for work and further study" (Yates \& McLeod, 2007, p. 61). Further, they indicated that many of the girls were "planning their careers in careful and strategic ways” and also had ““fall-back’ positions” (Yates \& McLeod, 2007, p. 61). Additionally, and in view of their research findings, Yates and McLeod (2007, p. 57) reported that most students - both boys and girls - were "quick to tell us that boys and girls today have ‘equal opportunities”, were "very conversant” with the language of equal opportunity rhetoric, could "identify practices or ideas that they thought were sexist”, could "easily label comments as 'sexist'”, and knew about "sexual harassment and gender equality". That noted, they also, reported that:

Overall we found gender reform and feminist ideas have had an uneven impact on the young people in our study. Equal opportunity language is now seen as the norm - but there is also an assumption that different things are 'normal' for girls and for boys (Yates \& McLeod, 2007, p. 57). 
Furthermore, and of significance given the focus of this paper, they also argue that:

... the impact of feminism and associated gender and social changes appears to have had a much stronger effect on girls than boys. Additionally, recent social changes and expectations that individuals need to change, to become flexible and to adapt to new circumstances, appear also to have had a stronger impact on girls' sense of their futures. The cultural imperatives to remake oneself, to reflexively construct a biography, to "be your own person" register differently for women and men, and intersect with feminist calls for women to make new choices (McLeod \& Yates, 2006, pp. 196-197).

\section{Methodology}

This paper, as signalled earlier, draws upon 327 surveys completed by female Year 12 students, those typically 17 years of age, in 9 schools across the State of Queensland, Australia. These surveys were administered and collated as part of a larger Australian Research Council (ARC) - a project which also involved the collection of 296 surveys completed by Year 12 males; with a total of 623 surveys completed and collated in all.

The ARC project, conducted over a period of three years, involved the collection of a range of data sources, including: surveys, focus group and individual interviews, response to stimulus writing and biography writing. The surveys under review here were administered in the initial phase of this research undertaking. 
This project employed the Accessibility/Remoteness Index of Australia (ARIA) (Department of Health and Aged Care, 2001) - the scale used by the Australian Bureau of Statistics as a standard classification and index of remoteness - in selecting school sites to ensure breadth of sampling in relation to location. These bands are estimated in relation to a location's accessibility to a range of goods, services and opportunities for social interaction: ARIA 1 Highly Accessible, ARIA 2 - Accessible, ARIA 3 - Moderately Accessible, ARIA 4 Remote, ARIA 5 - Very Remote.

The surveys under discussion in this paper comprise a sample representative of all five ARIA categories. The 327 surveys conducted as per ARIA band is as follows: Aria $1=92$ female respondents; Aria 2 = 84 female respondents; Aria $3=76$ female respondents; Aria 4/5 = 75 female respondents.

These surveys comprised of multiple choice and open-ended questions - the latter of which invited students to provide 'open' comment. Methodologically, a discourse analysis approach was employed to examine the surveys and as a means of identifying the emergent themes.

While the multiple sources used across the project as a whole served to provide rich data, it is to be noted that the survey, as an instrument, is not without limitation. At the most basic level for example, one such limitation is "related to the writing skills of the person completing” the survey (Patton, 1987, p. 11 see also Patton, 2002). Further limitations, and such that may well in part stem from that noted above, pertain to the "possible unsophistication and limited scope of the data that are collected” (Cohen, Manion \& Morrison, 2000, p. 245 as cited in Clough \& Nutbrown, 2003). Additionally, surveys are 
subject to the likelihood of limited flexibility of response and of the researcher being denied the opportunity to 'follow up' on competing or contradictory statements that may present (Cohen, Manion \& Morrison, 2000; Patton, 2002). Furthermore, surveys rely on selfreporting of/by the participant - another potential limitation (Kervin, Vialle, Herrington \& Okely, 2006).

For the purpose of this paper, the young women's responses to 2 survey questions serve as the focal point. These questions are:

1. In what way does being male or female influence your preferences?

[Question 7 on original survey]

3. Is there anything you can tell us about how being a boy or being a girl in your community might influence your future plans?

[Question 22 on original survey]

It is the case that the responses to these questions function in such a way as to elucidate the ways in which these young women viewed gender as an influence in their future lives, took up the neoliberal position, and moreover, how they did so in imagining and making (or in contemplation of such making) choices about their futures - their desired futures.

\section{Discussion}

Having reviewed the responses to the surveys completed by the Year 12 female students and conducted a detailed examination of the emergent data, it became overwhelmingly apparent that these young women had not only engaged with, but also firmly taken up, neoliberal discourse in the process of subjectification (Davies, 1993). It was the case that they had bought into the dominant imperative of the individual as actor - of individuals "as being responsible for conducting themselves, in the business of life, as an enterprise, a project, a 
work in progress” (Kelly, 2006, p. 18). So, too, did it become clear that in these young women's view, gender was to have no influence upon the construction of their life projects. Rather, gender was 'cast' as insignificant, as irrelevant, in what was to be the scripts - the biographies - of their life. That stated, and as one would expect given that data is not monolithic, some alternative storylines emerged acknowledging the influence or possible influence of gender, however, these were marginal.

As evidenced in the data presented below, it became very clear that these young women believed that nothing could, should or would affect them in planning for and enacting their futures. They were firm in their belief that this was the case, and that any 'extraneous' factor, in this instance gender, was to have no influence upon the narrative of their futures. Rather, and in line with neoliberal rationality, gender was to have no bearing on their 'choice' - and they had clearly constructed themselves as subjects of choices and aspirations (Rose, 1996a). They were to be the authors - and indeed individual authors - of their own biographies. It was the case that the young women's take-up of an individualist position became strongly apparent in their responses to the survey questions related to the possible influence of gender upon their future lives, their aspirations and expectations for the future. In relation to the question: "In what way does being male or female influence your preferences?" [Question 7 on original survey], the young women typically offered the following responses:

“Being female does not affect me at all. I have felt no pressure to aim for anything other than what I want.” (ARIA 1 Female)

“It doesn't really. I make my decisions as a person and not based on my gender.” (ARIA 1 Female) 
“I don't think it does. It depends on what influences you as an individual.” (ARIA 1 Female)

"It has nothing to do with it. If I wanted to do something I would do it.” (ARIA 2 Female)

"It doesn't affect my preferences because no matter if I was male or female I will do what I want to do.” (ARIA 2 Female)

"It has no influence. These are choices I have made, they are not influenced by gender discriminating issues.” (ARIA 2 Female)

“It doesn't, I'll do what I want whatever sex I am.” (ARIA 3 Female)

“It doesn't really influence my preference. I know that if I put my mind to something then I will achieve it, gender doesn't come into it.” (ARIA 3 Female)

“I don't believe it does.” (ARIA 4/5 Female)

“It doesn't. I was raised to believe that whatever gender I was I could [do] whatever I wanted ....” (ARIA 4/5 Female)

Tapping into the neoliberal notion of the entrepreneurial self, the 'self as driving force', the young women were adamant that their future life trajectories lay in their individual hands - 
each individual was to be the 'architect' of her own destiny. In this way, the young women actively positioned themselves as subjects who had embraced the rationality of neoliberalism. Once again, gender was viewed to be irrelevant, and particularly so given the (perceived) climate of equal opportunity. Asked to respond to the question: "Is there anything you can tell us about how being a boy or being a girl in your community might influence your future plans”? [Question 22 on original survey], the young women's responses were typified by the following:

“My future plans will be made of what I find I want to do when I'm ready. It's all based on individual choice and how far you want to pursue what you believe in.” (ARIA 1 Female)

"I don't see why being male or female should change someone's future plans. You can only do your best in life, so do it and you would have made it.” (ARIA 1 Female)

“In no way will my sex influence my future plans.” (ARIA 2)

"Your gender should have no impact ... if you really want something, you will do it anyway.” (ARIA 2)

"We have the right to make our own decisions and to follow our dreams. Nothing should create a negative influence." (ARIA 3 Female)

"Nothing or no one influences my decisions except me, regardless of sex ....” (ARIA 3 Female) 
"No. I have enough ambition to do what I want to do ... ."

(ARIA 4/5 Female)

“NO! In this modern day and age there isn't much discrimination

about gender.” (ARIA 4/5 Female)

The young women's conviction in their 'own' - autonomous - capacity to create their lives, and their dismissal of the notion of gender bearing any influence upon the ways in which they were able to do so, was firm. Such it was, that they questioned the researchers' position in regard to gender and, in doing so, the survey itself. For these young women, the survey questions were irrelevant - for gender was, in their view, immaterial to their lives and the ways in which they desired to enact such lives. Clearly, these young women were highly conversant with the language of equal opportunity rhetoric and most saw boys and girls as having equal opportunities today (see Yates \& McLeod, 2007). And, it is suggested here that the work of feminists, such as that of Queensland feminist bureaucrats who produced 'bumper stickers' espousing that “Girls can do anything”, that “Women can do anything”, may well have made inroads into the hearts and minds of these young women. That is, their message appears to 'ring true' for these young women who clearly desired to buy into the rhetoric (and practices) of equal opportunity for women. So it was, as evidenced in the data presented here, that many of these young women challenged the researchers' view that gender might in some way be of relevance to their future lives, engaged with equality opportunity rhetoric and firmly embraced neoliberal discourse in doing so. 
"I'd like to point out the irrelevance of these questions, no one really discriminates against our gender. I suggest that you people update your survey.” (ARIA 4/5 Female)

“Commenting on this topic would insult my intelligence. I don't care what gender I am, the point is that I am a person and I choose what I want.

... WE ARE EQUAL! (In case you haven't noticed I'm a very antisexist person!).” [original capitalisation] (ARIA 4/5 Female)

"I honestly don't think your gender has something to do with your influence on your preference. I believe if you want to do that profession or job you will do anything to get it. Don't let your gender hold you back. Maybe rephrase the question.

... GIRLS CAN DO ANYTHING!! What do you think I am, STUPID!”

... YOU ARE WHAT YOU ARE! PICK DIFFERENT Q'S." [original capitalisation] (ARIA 4/5 Female)

\section{Conclusions}

The data presented here elucidate the ways in which the young women surveyed had, overwhelmingly, taken up a neoliberal position. They had clearly bought into the dominant imperative of individualisation. In doing so, they had positioned themselves as - or indeed aspired to be positioned as - the actor of their own lives, the author of their own biographies. They endeavoured to construct themselves as active individuals who were the subjects of choice and aspiration, and to "enterprise themselves" (Fitzsimmons, 2002, p. 3). They were 
robust in their hope for living a 'life-as-planned', to make of their life what they wanted to. It, too, became manifestly apparent that gender was - from the young women's position - to have no influence upon this enterprise, upon the ways in which they aspired to live out their lives. Gender as a possible influence was, in essence, under erasure (Davies, 1993) from the narrative, the biography, of their lives. They would not be 'encumbered' by gender - for it seemed to them, that any influence gender may have to bear upon the lives of women was a thing of the past.

And while, as feminists, there is much for us to celebrate about a generation of young women who exhibit a robust belief that their futures lay in their own hands, who are seemingly ready to 'take on the world' in these new neoliberal times, it is also important to acknowledge the uncertain nature of such an undertaking, particularly as it comes to be played out in these unstable new times. It should be recognised that the “'do-it-yourself biography” is always a 'risk biography' ... and one that can quickly become a 'breakdown biography'” (Beck \& Beck-Gernsheim, 2001, p. 4) and the implications of this for young women need be considered.

So, too, while we may be buoyed by the apparent success of feminist initiatives such as the 'bumper sticker', the young women's take-up of equal opportunity rhetoric and their understanding that females have equal rights today (legally at least), their dismissal of the possible influence of gender upon their lives may nonetheless give cause for concern. For if the theories regarding the impact of neoliberalism on lives - as connected to life trajectories as purported by prominent researchers such as Beck, Beck-Gernsheim and Rose are found to be correct, then these young women, in all their unrelenting optimism, may be seen to have underestimated the extent to which the 'biography-of-possibility' is constrained in very real 
ways by structural factors such as gender. Furthermore, and in light of the compelling and indeed disheartening findings of the research commissioned by the World Economic Forum (Lopez-Carlos \& Zahidi, 2005), their optimism - and indeed their imagining(s) of a life unencumbered by gender inequalities - could be seen to be misplaced. For it is the case that social inequalities persist between men and women and impact upon the lives of women in tangible ways (Beck \& Beck-Gernsheim, 2002). And while Australia may well be categorised as a "woman-friendly" country against the measures of the World Economic Forum, there is much work yet to be done to dismantle gender inequalities if the desired and imagined futures of these young women are to become more than just that - more than mere imagining(s). 


\section{References}

Abbott-Chapman, J. (2000). Time Out Spaced Out. Youth Studies Australia, 19(1), 21-25.

Ainley, J. \& McKenzie, P. (1999). The influence of school factors. In Dusseldorp Skills Forum, Australia 's young adults: The deepening divide. (pp. 105-116). Sydney:

Dusseldorp Skills Forum.

Alloway, N., Dalley, L., Patterson, A., Walker, K. \& Lenoy, M. (2004). School students making education and career decisions: Aspirations, attitudes and influences. Commonwealth of Australia: DEST.

Alloway, N., Gilbert, P., Gilbert. R. \& Muspratt, S. (2004). Factors Impacting on Student Aspirations and Expectations in Regional Australia. Commonwealth of Australia: DEST.

Bauman, Z. (1992). Intimations of Postmodernity. London: Routledge.

Beck, U. (1992). Risk Society: Towards a New Modernity. London: Sage.

Beck, U. \& Beck-Gernsheim, E. (1996). Individualization and 'Precarious Freedoms': Perspectives and Controversies of a Subject-oriented Sociology. In P.Heelas, S. Lash \& P. Morris (Eds.), Detradition. Cambridge, Massachusetts: Blackwell.

Beck, U. \& Beck-Gernsheim, E. (2001). Individualization. London: Sage. 
Beck, U. \& Beck-Gernsheim, E. (2002). Individualization: Institutionalized Individualism and Its Social and Political Consequences. London: Sage.

Beck, U., Bons, W. \& Lau, C. (2003). The Theory of Reflexive Modernization: Problematic, Hypotheses and Research Programme. Theory, Culture and Society, 22(2), 1-33.

Bryce, J. \& Anderson, M. (2008). What can be learned from the roller coaster journeys of young people making ultimately successful transitions beyond school?’ Australian Journal of Career Development, 17(1), 41-49.

Clough, P. \& Nutbrown, C. (2003). A student's guide to methodology. London: Sage.

Collins, C., Kenway, J. \& MacLeod, J. (2000). Factors Influencing the Educational Performance of Males and Females in School and Their Initial Destinations After Leaving School. Commonwealth Department of Education, Training and Youth Affairs.

Davies, B. (1993). Shards of Glass: Children Reading and Writing Beyond Gendered Identities. St Leondards, New South Wales: Allen \& Unwin.

Davies, B., Browne, J., Gannon, S., Honan, E. \& Somerville, M. (2005). Embodied Women at Work in Neoliberal Times and Places. Gender, Work and Organization, 12(4), 343-362. 
Department of Health and Aged Care and the National Centre for Social Applications of Geographical Information Systems. (2001). Measuring Remoteness:

Accessibility/Remoteness Index of Australia. Revised Edition. Occasional Papers: New Series Number 14. Information and Research Branch, Department of Health and Aged Care.

Dusseldorp Skills Forum. (2006a). Fearless and Flexible: Views of Gen Y. A Qualitative Study of People Aged 16 to 24 in Australia. Sydney: Dusseldorp Skills Forum.

Dusseldorp Skills Forum. (2006b). How Young People Are Faring 2006: Key Indicators. An Update about the Learning and Work Situation of Young Australians. Sydney: Dusseldorp Skills Forum.

Dwyer, P. (2000). And the Linear Model Goes On and On. Youth Studies Australia, 19(1), 16.

Dwyer, P., Harwood, A. \& Tyler, D. (1998). Life Patterns, Choices and Careers: 1991-1998. Research Report 17. Melbourne: Youth Research Centre, University of Melbourne.

Dwyer, P., Harwood, A. \& Tyler, D. (1999). Seeking the Balance: Risk, Choices and Life Priorities in the Life Patterns Project 1998/9. Working Paper 19. Melbourne: Youth Research Centre, University of Melbourne.

Dwyer, P. \& Wyn, J. (2001). Youth, Education and Risk: Facing the Future. London: Routledge/Falmer. 
Fitzsimmons, P. (2002). Neoliberalism and Education: The Autonomous Chooser. [retrieved 25 March 2008].

Furlong, A. \& Cartmel, F. (1997). Young People and Social Change: Individualisation and Risk in Late Modernity. Buckingham: Open University Press.

Gilbert, P. \& Gilbert, R. (1995). What's Going On? Teenage Girls'Experiences of Educational Disadvantage. Canberra: McMillan/Department of Education and Training.

Harris, A. (2004). Future Girl: Young Women in the Twenty-First Century. London: Routledge.

http://writing.colostate.edu/guides/research/survey/com2d1.cfm. [retrieved 26 December 2010].

James, R. (2001). Participation disadvantage in Australian higher education: An analysis of some effects of geographical location and socioeconomic status. Higher Education, 42, 455-472.

Kelly, P. (2006). The Entrepreneurial Self and 'Youth-at-risk': Exploring the Horizons of Identity in the Twenty-First Century. Journal of Youth Studies, 9(1), 17-32.

Kenyon, P., Sercombe, H., Black, A. \& Lhuede, D. (2001). Creating Better Educational and Employment Opportunities for Rural Young People. A Report to the National Youth Affairs Research Scheme. Hobart: Australian Clearinghouse for Youth Studies. 
Kervin, L., Vialle, W., Herrington, J. \& Okely, T. (2006). Research for educators. Melbourne: Thomson Social Science Press.

Lopez-Claros, A. \& Zahidi, S. (2005). Women's Empowerment: Measuring the Global Gender Gap. Geneva: World Economic Forum.

Looker, D. E. \& Dwyer, P. (1998). Rethinking Research on Educational Transition of Youth in the 1990s. Research in Post-Compulsory Education, 3(1), 5-23.

Marks, G., Fleming, N., Long, M. \& McMillan, J. (2000). Patterns and Participation in Year 12 and Higher Education in Australia: Trends and Issues. LSAY Research Report No. 17. Melbourne: Australian Council for Educational Research [ACER].

McLeod, J. \& Yates, L. (2006). Making Modern Lives: Subjectivity, Schooling, and Social Change. Albany: State University of New York Press.

Mercurio, A. \& Clayton, L. (2001). Imagining Themselves, Imagining Their Futures. Indigenous Australian Students Completing Senior Secondary Education. Adelaide: Senior Secondary Assessment Board of South Australia.

O’Malley, P. (1996). Risk and Responsibility. In G. Barry, T. Osborne \& N. Rose (Eds.), Foucault and Political Reason: Liberalism, Neo-liberalism and Rationalities of Government. London: UCL Press. 
Patton, M. Q. (1987). How to Use Qualitative Methods in Evaluation. Newbury Park, CA: Sage.

Patton, M. Q. (2002). Qualitative Research and Evaluation Methods. (3 ${ }^{\text {rd }}$ ed.) Thousand Oaks, CA: Sage.

Rose, N. (1992). Governing the Enterprising Self. In P. Heelas \& P. Morris (Eds.), The Values of the Enterprise Culture: The Moral Debate. London: Routledge.

Rose, N. (1996a). Governing “Advanced” Liberal Democracies. In G. Barry, T. Osborne \& N. Rose (Eds.), Foucault and Political Reason: Liberalism, Neo-liberalism and Rationalities of Government. London: UCL Press.

Rose, N. (1996b). Inventing Our Selves: Psychology, Power and Personhood. Cambridge: Cambridge University Press.

Rose, N. (1999). Powers of Freedom. Cambridge: Cambridge University Press.

Steedman, C. (2000). Enforced Narratives: Stories of Another Self. In T. Cosslett, C. Lury \& P. Summerfield (Eds.), Feminism and Autobiography: Texts, Theories and Methods. London: Routledge.

Trent, F. \& Slade, M. (2001). Declining Rates of Achievement and Retention: The Perceptions of Adolescent Males. Canberra: Department of Education, Training and Youth Affairs 
White, R. \& Wyn, J. (2008). Youth and Society $\left(2^{\text {nd }}\right.$ ed). Melbourne: Oxford University Press.

Woodman, D. (2004). Responsibility and Time For Escape: The Meaning of Wellbeing to Young Australians. Melbourne Journal of Politics, 29, 82-95.

Wyn, J. (2004). Becoming Adult in the 2000s: New Transitions and New Careers. Family Matters, 68, 6-12.

Wyn, J. \& Woodman, D. (2006). Generation, Youth and Social Change. Journal of Youth Studies, 9(5), 495-514.

Yates, L. \& McLeod, J. (2007). 12 to 18: A Qualitative Longitudinal Study of Students, Values and Difference in Australian Schools. Deakin (ACT): Australian Curriculum Studies Association. 